\title{
Spectrum of Ocular Injuries at Stone Crushing Industry
}

\author{
MUHAMMAD SAJID MUNIR ${ }^{1}$, BURHAN RASHEED ${ }^{2}$, MUHAMMAD ZUBAIR ${ }^{3}$, HASSAN SHAUKAT4, ABRAR UL HASSAN \\ PIRZADA ${ }^{5}$, MUHAMMAD SHOAIB ${ }^{6}$ \\ ${ }^{1}$ Assistant Professor Ophthalmology, Niazi Medical and Dental College Sargodha. \\ ${ }^{2}$ Senior Registrar Radiology Department, Rai Medical College Sargodh \\ ${ }^{3}$ Associate Professor of Surgery, Niazi Medical and Dental College Sargodha. \\ ${ }^{4}$ Senior Registrar General Surgery, Niazi Medical \& Dental College Sargodha \\ ${ }^{5}$ Assistant Professor of Plastic Sugery, Azra Naheed Medical College, Lahore. \\ ${ }^{6}$ Associate professor, Department of Surgery, Azra Naheed Medical College, Lahore \\ Correspondence to Dr. Muhammad Sajid Munir, Email: drmsmunir@yahoo.com
}

\begin{abstract}
Purpose: To determine the pattern, proportion, burden and impact of eye injuries presenting at emergency department of Niazi Medical And Dental College from stone crushing industry Sargodha.

Method: The study was conducted from Jan 2018 to Dec 2019 at Niazi Welfare Teaching Trust Hospital affiliated with Niazi Medical and Dental College Sargodha. It was prospective interventional study. Patient were selected on the basis of convenience sampling method. The detail history of every patient was taken like Age, sex, site, time and source of trauma. Examination carried out by torch and slit lamp and if necessary retinal examination also done. Patients are investigated for general anesthesia if surgery needed. Otherlnvestigations like B-scan and X-ray done to rule out Intraocular foreign body in patients with history of foreign body in eye. CT scan and MRI done arealso done along with headinjury involvement.

Results: 250 cases were enrolled in this study. Out of which $90 \%$ were presented In emergency and $10 \%$ were referral from dispensary or general practitioner. The major source of injury was blasting at mountains. Next important was stone crushing. Most type of injury was blunt trauma in which corneal foreign body was top of list and other type of blunt trauma need medical treatment in most cases. Around 18\% patients admitted for eye surgery intervention. Around 10\% referred to Vitreo retinal eye surgeon for further Intervention. Most workers injured at stone crushing industry they were illiterate.

Conclusion: Eye trauma is a important cause of unilateral and bilateral cause instone crushing industry. These workers are young and few percentage loss of total vision. It is great trauma to their families. Most are illiterate and belong to poor socioeconomic status so socially and psychologically they are great burden on the country. There should be health insurance for them. Ministry of mining should made strict rules and make their proper law enforcement.
\end{abstract}

Keywords: ocular injuries, penetrating Eye Injury, blindness

\section{INTRODUCTION}

Ocular trauma is an important cause of uniocular visual impairment and blindness in the younger and economically active age group ${ }^{1}$. Beside visual loss their working and earning capacity also badly damage and create a big burden socially and economically on society ${ }^{2}$. Although occular trauma affects the all age groups. Regarding blunt trauma Penetrating injury of the eye represents a major threat to the vision in the work place, home, school and play ground ${ }^{3,4}$. Serious ocular injuries like globe rupture, orbit damage permanently loss the whole productive years of life of young people. In the past not too much work is done on this topic particularly ocular injuries in industry sector. It is very important industry because huge number of our population is attached with this industry for their earning and mostly belong to the lower socioeconomic status $^{5,6}$.

After agriculture, industry is our big sourceof earning in our country. So in this topic we focus this segment. It is the biggest stone crushing industry of Pakistan situated near the SARGODHA. A huge number of population is attached with this industry in different disciplines include labourers involved in blasting mountains, mining workers,

Received on 26-12-2019

Accepted on 21-05-2020 crushing stone workers, maintenance labourers, trucks \& tractor trolley drivers and stone carriage workers and small hotel industry. Our Hospital is situated near to this industrial area andin this area there is not too much good emergency facility is available for the workers only one THQ hospital around $4-5 \mathrm{~km}$ distance away and two to three dispensaries are present here. Even private hospital facility is also not well sufficient. So variety of trauma is being referred to Sargoda DHQ and private hospitals. As this hospital is affiliated to medical college having qualified staff, has become the referral center for last 2 years and the numbers of patients are increasing with the passage of time.

Regarding Spectrum of ocular injuries, this study helps us in planning better health facilities and safety strategies for the prevention and treatment of occular injury. The young man power is our future assets.

\section{MATERIAL AND METHOD}

The study was conducted from Jan 2018 to Dec 2019 at Niazi Welfare Teaching Trust Hospital affiliated with Niazi Medical and Dental College Sargodha...It was prospective interventional study. Patients were selected on the basis of probability convenience sampling method. Most of the patients come from our hospital emergency department. The detailed history of every traumatic patient was taken with particular reference like their age, time of injury, type 
of injury, occupation and mechanism of injury and recorded. After that all patients were thoroughly examined. Visual acuity is checked by snellen's chart. Initial examination was done with torch and slit lamp and if possible retinal examination also performed. Relevant investigations like Blood Complete andchest $\mathrm{x}$-ray for general anesthesia done. Specific investigations like $\mathrm{x}$-ray orbit, B-scan of the orbit done for intraocular foreign body. X-ray skull and CTbrain is done to rule out head injury problems.Patients with superficial injuries like abrasion, foreign body in cornea discharged while patients of serious injuries like penetrating injury, globe perforation, corneal perforation were admitted and properly managed. Cases having Intraocular foreign body, retinal detachment vitreous haemorrhage were reffered to vitreous retinal surgeon after giving him necessary primary treatment.

\section{RESULTS}

The total number of patients included in this study were 250 in which 225 were come from our energy department and 25 was reffered from the dispensary and general practitioner in stone blasting areas. Almost total ocular trauma was come from stone blasting area as it is spread in $25-30 \mathrm{~km}$.

Table 1: Referral source

\begin{tabular}{|l|l|}
\hline Source & $\mathbf{n = 2 5 0}$ \\
\hline Emergency & $225(90 \%)$ \\
\hline Referral & $25(10 \%)$ \\
\hline
\end{tabular}

Table 2: Source of injury

\begin{tabular}{|l|l|}
\hline Source of injury & $\mathbf{n = 2 5 0}$ \\
\hline Mountain Blasting & $155(62 \%)$ \\
\hline Stone crushing & $60(24 \%)$ \\
\hline Stone loading & $20(8 \%)$ \\
\hline Stone transportation & $10(4 \%)$ \\
\hline Mechanical work shop & $5(2 \%)$ \\
\hline
\end{tabular}

Table 3: Type of injury $(n=250)$

\begin{tabular}{|l|l|}
\hline Type of injury & $\mathbf{n}$ \\
\hline Blunt trauma & $\mathbf{2 0 0 ( 8 0 \% )}$ \\
\hline Anterior segment & $119(59.5 \%)$ \\
\hline Corneal foreign body & $23(11.5 \%)$ \\
\hline Abrasion & $17(8.5 \%)$ \\
\hline Hyphaema & $14(7 \%)$ \\
\hline Traumatic cataract & \\
\hline Posterior segment & $11(5.5 \%)$ \\
\hline Vitreous haemorrhage & $9(4.5 \%)$ \\
\hline Retinal detachment & $7(3.5 \%)$ \\
\hline Intraocular foreign body & $\mathbf{3 0 ( 1 2 \% )}$ \\
\hline 2. Globe penetration & $\mathbf{1 5 ( 6 \% )}$ \\
\hline 3. Globe perforation & $\mathbf{5 ( 2 \% )}$ \\
\hline $\begin{array}{l}\text { 4. Others (lid and face burn after } \\
\text { blasting, facial and orbital fracture) }\end{array}$ & \\
\hline
\end{tabular}

Table 4: Educational status of patients $(n=250)$

\begin{tabular}{|l|l|}
\hline Literate & $\mathbf{n}$ \\
\hline Primary & $32(12.8 \%)$ \\
\hline Secondary & $25(10 \%)$ \\
\hline Higher & $12(4.8 \%)$ \\
\hline Illiterate & $181(72.4 \%)$ \\
\hline
\end{tabular}

Regarding source of injury that major source was mountain blasting. It is very dangerous trauma because most of patients loss their both eyes. They have surgical and orthopedic injuries as well. While in other source of injuries like road traffic accidents (RTA), kitchenware injuries, hammering and chiseling, mostly eyes are involved but rest of body is spared. Regarding type of injury blunt trauma was most common. In emergency most patients present with foreign body problem. Almost $25 \%$ of patients need admission for corneal repair and globe repair. 5\%-10\% patients are referred to vitreoretinal surgeon for further treatment. Most of workers attached with the industry are illiterate. Around $30 \%$ population is primary and secondary level of education.

\section{DISCUSSION}

Ocular trauma is one of the major causes of uniocular blindness. But in our study the major source of trauma is blast injury. So many patients had bilateral, visual loss. It is very shocking for society and country. They are big problem for their family because they loss of vision in young age. So it is big emotional trauma for their family and whole society. They also belong to the low socioeconomic status as well. The eye emergency make about $20 \%$ of total emergency trauma come at Niazi Welfare Teaching Trust Hospital from January 2018 to December 2019. We attend total 250 number of cases out of which $59.5 \%$ have foreign body in their eyes. $30 \%$ need conservative treatment. Regarding type of injuries with different studies conducted in Pakistan and other countries around 13\% patients reffered to vitreoretinal surgeon ${ }^{7,8}$. It also agree with many studies. But it contradict with one study conducted.The population of hospital admission in this study was $18 \%$ which was in between two studies conducted by Panda and colleagues $(27.8 \%)$ and other was conducted in Ireland $(8.4 \%)^{9,10}$.

Most of injuries were found in males and all patients in our study were male because they come from stone crushing industry this thing also coincides with other studies $^{11,12}$. In our study most of the patients were illiterate. This things varies from study to study. Some study conducted in city hospital or urban area their literacy rate is more. The most important feature of our study is that major portion of source of injury in this study is mountain blast injury. This thing differ it from routine articles of ocular trauma. Because this trauma has a deleterious effects. Most of the patients loss their complete vision and they are young at their maximum years of productivity. Even many died in blasting at spot before reaching hospital as tell by their colleagues. They belong to poor socioeconomic status. They were mostly illiterate and have no health insurance of their life, families and work. A lot of workers died every year in stone blasting industry. When we compare with different study one study data was very shocking in whole they show bilateral damage of eyes in $78.4 \%$ cases and out of which $37.3 \%$ were totally blind ${ }^{13,14,15}$.

\section{CONCLUSION}

The prevalence of blindness caused by different type of blasting rocks and mountains is quite high. The resulting psychological financial and social loss to the patients and 
their families is tremendous and has not been adequately highlighted. These injuries are great burden on our country economy. There should be health insurance programme. There should strict enforcement of law. Regarding preventive measure and sophisticated equipments the ministry of mining should pay great attention on these things.

\section{REFERENCES}

1. Attebo K, Mitchell P, Smith W. Visual acuity and the causes of visual loss in Australia. Ophthalmology. 1996; 103: 357-64.

2. Dannenberg AL, Parver LM, Brechner RJ. Penetrating eye injuries in the work place. The National EyeTrauma System Registry. Arch Opthalmol.1992; 110:843.

3. Peate WF. Work-related eye injuries and illnesses. Am Fam Physician. 2007;75:1017-22.

4. Esmaeli B, Elner S, Schork MA, Elner VM. Visual outcomes and ocular survival after penetrating trauma. Ophthalmology. 1996;102:393-400.

5. Oum BS, Lee JS, Han YS. Clinical features of ocular trauma in emergency department. Korean J Ophthalmol. 2004;18:7078.

6. Mine Blast Injuries ocular and Social Aspects. Muzaffer W, Khan MD, Akber MK, Malik AM, Serrano OM. 1350,01 Jun 2000,84(6): 626-30
7. Bull N. Mandatory use of eye protection prevents eye injuries in the metal industry. Occup Med (Lond). 2007;57:605-06

8. Khan MD, Muhammad S, Islam Z, Khattak MN. An 11.5 year review of ocular trauma in the NWFP of Pakistan. Pak $J$ Ophthalmol. 1991; 7: 15-18.

9. Panda A, Bhati JM, Dayal Y: Ocular injuries, a socioeconomic importance. Afro-Asia-J-Ophthalmol. 1985; 4: 16374.

10. Canavan YM, O' Flaherty MJ, Archer DB, Elword JH. A 10 year surety of eye injuries in Northern Ireland, 1967-1976. Br J Ophthalmol. 1980; 64: 618-25.

11. Khan MD, kundi N, Mohammed Z, Nazeer AF. A 6 and half years survey of Intraocular and intraorbital foreign bodies in NWFP of Pakistan. Br J Ophthalmol. 1987; 71 : 716-19.

12. Ilsar M, Chirambo M, Belkin M. Ocular injuries in Malawi. Br J Ophthalmol.1982; 66: 145-8.

13. Katz J, Tielsch JM. Lifetime prevalence of ocular injuries from Baltimore Eye Suryey. Arch Opthalmol. 1993; 111: 1564.

14. Fea A, Bosone A, Rolle T, Grignolo FM. Eye injuries in an Italian urban population: report of 10,620 cases admitted to an eye emergency department in Torino. Graefes Arch ClinExp Opthalmol.2008; 246: 175-179.

15. Keklikci U, CelikY, Cakmak SS, Sakalar YB, Unlu MK. Evaluation of perforating eye injuries by using cluster analysis. Ann Opthalmol(Skokie). 2008;40:87-93. 